http://dx.doi.org/10.1590/0102-311XCO041015

\author{
Ana Maria Costa \\ Escola Superior de Ciências \\ da Saúde, Brasília, Brasil. \\ Centro Brasileiro de Estudos \\ de Saúde, Rio de Janeiro, Brasil. \\ Asociación Latinoamericana \\ de Medicina Social, México DF, \\ México. \\ dotorana@gmail.com
}

\section{Anotações sobre o artigo de Paulo Gadelha}

$\mathrm{O}$ artigo de Paulo Gadelha, como ele bem assinala ao concluí-lo, foi escrito sob uma complexa conjuntura política que ameaça a democracia e o estado de direito, cujos desdobramentos são de difícil previsão. É nesse contexto que o autor traz à cena o necessário debate quanto às perspectivas para a 15a CNS. O tom e o lugar adotado, não apenas confere legitimidade às suas reflexões e propostas como também expressam o compromisso e a aposta que deposita sobre a democracia participativa e a participação da sociedade no processo de conquista e efetivação do direito universal à saúde.

As preocupações com as Conferências de Saúde constituem uma quase unanimidade no setor da saúde. Institucionalizadas para conferir sentido à participação social na formulação de diretrizes para as politicas de saúde, essas conferências acabaram desgastadas e, para muitos, se esvaziaram do papel original. Sob essa perspectiva, o autor insinua que a participação social está ainda muito distante do que poderia ser como resultado de uma efetiva força política hegemônica no interior da sociedade. A pergunta que se faz necessária é se nesse contexto a sociedade por meio da sua participação política seria capaz de sustentar o projeto político constitucional para a saúde?

Uma questão preocupante apontada é a forma fragmentada de atuação dos diferentes e numerosos atores sociais que, sem contar com a presença do amálgama de uma consciência e prática política que seja pautada nos interesses coletivos e nos valores da solidariedade social, acabam contribuindo para aumentar a fragilização que impede a necessária pressão política da sociedade por políticas e direitos sociais universais.

$\mathrm{O}$ artigo, entretanto, parte de uma expectativa positiva em relação às conferências, não sem criticar quanto à fantasiosa expectativa quase generalizada de revivermos a 8a CNS de 1986, cujas características e contextos políticos fizeram dela a mais impactante de todas as conferências nacionais de saúde. Bem lembrado que fazer outra oitava tem sido o objetivo desde a 12a CNS, em 2003. Foi justamente nessa época que tivemos o prazer de trabalhar junto com o Gadelha compondo, ainda com Sarah Escorel, o trio de relatores da 12 a $\mathrm{CNS} 1$.

Sob uma abordagem positiva, o artigo valoriza a inovação das "Conferências Livres" por “abrir a pauta da saúde para o conjunto da sociedade" (p. 2051) necessária ao enraizamento do pertencimento social que o SUS requer à sua própria sobrevivência nos dias atuais. Não discordamos disso, mas a expectativa de impacto real dessa modalidade de conferência no resultado final da 15a CNS é ainda uma incógnita.

Sobre as Conferências Livres, primeiro é importante valorizar a ampliação dos debates, a formação de consciência crítica e o fortalecimento de mecanismos participativos como estratégia concreta de aperfeiçoamento de uma democracia participativa radical, para além das instâncias institucionalizadas de participação e controle social e, portanto, assim, sair dos muros das conferências municipais e estaduais. $\mathrm{O}$ segundo ponto seria garantir que o produto desses debates desembocasse no resultado final da 15a CNS, ou seja, no seu relatório. Mas isso acabou se tornando uma questão pendente por antecipação, impossibilitada pelo processo de relatoria estabelecido, que toma como base exclusiva as conferências formais dos municípios e estados.

O sistema informatizado de construção de relatórios de conferências teve origem justamente na 12a CNS e estivemos diretamente envolvidos na sua concepção, na esperança de que o mesmo pudesse vir a ser uma ferramenta útil para conferir maior racionalidade, densidade política aos relatórios, convergindo propostas e tornando possível uma leitura que agregasse o que procede das conferências preparatórias à etapa nacional. Não deu certo e acabou se transformando em uma ferramenta eficiente para vigilância e garantia quanto ao fluxo ou andamento das propostas de um grupo, município ou conselheiro, no qual a relatoria é avaliada positivamente desde que uma proposta de base local reapareça de forma semelhante de preferência, lá na etapa nacional.

Para além das demandas fragmentadas e da forte presença do corporativismo nos diversos grupos sociais, buscar razões ou argumentos para interpretar a força dessa tendência de produção de relatórios de conferências nacionais de saúde envolve repensar criticamente sobre o que Gadelha chama de "sistema de controle social", pois tido como sistema, cujas partes são interdependentes, é natural que se nele entra algo, à frente deve sair de alguma forma ao final do processo ocorrido no tal sistema. Mas é preciso reafirmar que a participação e o controle social quando instituídos em nada se aproximavam dessa conotação de "sistema", bastando relembrar que conselhos e conferências existem e se referem ao respectivo âmbito de sua existência. Isso significa que o conselho municipal representa e pertence àquele território de gestão municipal, e conexões com níveis regionais ou estaduais 
são desejáveis mas não se interligam de forma dependente como se espera de um sistema. Tem justificativa de existência para o seu âmbito.

Um dos desafios atuais seria criar alternativas participativas e de controle social, ajustadas e adequadas à concepção de Redes de Saúde, organizadas nas bases territoriais regionais, sem comprometimento da arquitetura instituída. Pergunto então ao autor se desconstruir essa concepção não seria uma oportunidade de libertar conselhos e conferências dessa configuração de "sistema de controle social” que restringe, burocratiza e fragiliza a participação? Lembrando ainda que nesse caso, ao ignorar a riqueza dos debates livres não estamos descartando a possibilidade de influir no resultado final da 15a cNS. Criar mecanismos para garantir que sejam incorporadas todas as análises e propostas oriundas do ampliado debate ocorrido em todas as modalidades - livres ou institucionalizadas - não representa avanço ou revigoramento das conferências?

Mas o artigo prossegue desenhando o cenário para debater as possibilidades e os desafios para a 15a CNS, analisando e contextualizando, de forma breve, mas apropriada, os principais aspectos, avanços e contradições relacionados ao SUS, sem deixar de ressaltar suas virtudes e seus graves problemas e impasses. De forma oportuna o artigo convoca um horizonte à realidade, começando por propor o abandono da memória fantasiosa da 8ạ, realizada em outros contextos históricos e políticos. Com isso, o autor lança o desafio de interpretar o processo e a evolução das conferências como estratégia para buscar alternativas. Acrescentaria que não apenas analisar as conferências, mas as complexas conjunturas políticas do Estado brasileiro que vêm desenhando e convivendo com cenários cada vez mais distanciados do modelo beveridiano da seguridade social presente na nossa Constituição cidadã!

Se o pretendido é que a sociedade brasileira alimente uma hegemonia com força política para avançar e consolidar os direitos sociais, antes que os mesmos sejam definitivamente destruídos, o que esperar da 15a CNS?

Com a conjuntura setorial marcada por tendências inerciais ou regressivas aos avanços, seria possível esperar da sociedade brasileira prospectar cenários e definir outros rumos políticos para a saúde a partir das conferências? Aqui, tal como ele nos convocou à realidade do momento da 15ạ, sou quem agora coloca sob questão esta possibilidade para a 15a CNS. Isso não significa retardar o passo, mas saber que o caminho é e será ainda bem longo, no qual as conferências podem representar pequenos atalhos que nem sempre diminuem a distância. Com isso, gostaria de dizer que precisamos bem mais do que as conferências possam oferecer ao país, mas alguma mudança pode fazer diferença nos tempos futuros, desde que agregue a este processo força e poder político.

E como bem disse o autor, os atores e cenários presentes na saúde são muitos, conflituosos e nem sempre virtuosos. E, concordando uma vez mais, é preciso ampliar e envolver poderes, atores, setores... Só não podemos esquecer que, sem a consciência crítica e o poder popular, o direito à saúde ficará como joguete dos interesses ilegítimos presentes no interior do Estado brasileiro, privatizando, mercantilizando e financeirizando o setor e transformando o SUS, sistema criado para ser universal e de qualidade, em alternativa de assistência à saúde para os que não podem pagar e que podem ser tratados de qualquer forma.

Mas os momentos de crise não podem ser desprezados, senão fortemente valorizados como possibilidade para que ocorram inovações ou mudanças. E a crise é grave, a começar pela insustentabilidade financeira do SUS. Termino este breve comentário ao debate do artigo de Paulo Gadelha declarando que, como ele, aposto nas oportunidades que a 15 a CNS possa proporcionar na reinvenção da saúde, a partir do que já avançamos e conquistamos com o SUS. Desde que não sejam abandonadas as suas bases constitucionais.

1. Ministério da Saúde. 12a Conferência Nacional de Saúde: Conferência Sergio Arouca. Relatório final. Brasília: Ministério da Saúde; 2004. (Série D. Reuniões e Conferências). 